\title{
PSEUDONYM AND PERSONA MANAGEMENT IN PSYCHOANALISYS APPROACH AMONG J-POP FANS IN SOCIAL MEDIA.
}

\author{
${ }^{1)}$ Pinckey Triputra, ${ }^{2)}$ Rewindinar \\ ${ }^{1}$ Universitas Indonesia \\ Jl. Margonda Raya, Pondok Cina, Kecamatan Beji, Kota Depok, Jawa Barat \\ ${ }^{2)}$ Universitas Sahid Jakarta \\ Jl. Prof. DR. Soepomo No.84, RT.7/RW.1, Menteng Dalam, Kec. Tebet, Kota Jakarta Selatan
}

Diterima 05 Desember 2019 / Disetujui 27 Maret 2020

\begin{abstract}
The development of communication technology makes a new form of persona management strategies. Facebook is one of social media, which can make the borders of public persona and private persona to be blurred and invisible. This research aims to explore the persona management in pseudonym practice through psychoanalysis approach by Japanese popular culture's fans on Facebook by separating their personas in RL (Real Life) account and fannish account. This research is a qualitative research and using constructivism paradigm. Data collection was obtained by unstructured interviews submitted to two Facebook users. The data is then processed and analyzed interpretively. Study found that the main motive of fans using pseudonimity in social media is to avoid the stereotype threats from their real-life society. Virtual ethnography methods are also used which depart from virtual participatory observation methods for pseudonym accounts and participant RL accounts Study also found that there's a new form of persona management strategies by using social media's technology features such as blocking, unfriend-ing, and using privacy setting feature, and the other strategies. So, their persona is public yet private towards some audience. Keywords; fandom, persona, pseudonym, fans, popular culture.
\end{abstract}

\begin{abstract}
ABSTRAK
Perkembangan teknologi komunikasi menciptakan bentuk baru dari strategi manajemen persona. Facebook adalah salah satu media sosial yang dapat membuat batasan sehingga persona publik dan privat menjadi kabur dan tidak terlihat. Penelitian ini bertujuan untuk mengeksplorasi manajemen persona dalam praktik pseudonim melalui pendekatan psikoanalisis yang dilakukan para fans budaya populer Jepang yang melakukan pemisahan persona mereka di akun RL (Real Life) dan akun fans. Penelitian kualitatif ini menggunakan paradigma konstruksivisme. Pengumpulan data diperoleh dengan wawancara tidak terstruktur yang diajukan kepada dua orang pengguna Facebook. Data kemudian diolah dan dianalisis secara interpretif. Metode virtual ethnography juga digunakan yang berangkat dari metode observasi partisipatif secara virtual untuk akun pseudonim dan akun RL partisipan. Temuan studi menunjukan terdapat motif utama dari fans yang menggunakan pseudonim dalam media sosial yaitu untuk menghindari ancaman stereotype dari kehidupan sosial yang nyata. Studi juga menemukan adanya bentuk baru dari strategi manajemen persona dengan menggunakan fitur teknologi sosial media seperti blocking, unfriend-ing, privacy setting dan lainnya. Dengan demikian persona mereka bersifat publik karena disebarluaskan melalui media sosial namun tetap bersifat pribadi dalam hubungannya dengan pengguna media sosial lainnya.
\end{abstract}

Kata kunci; fandom, persona, pseudonim, fans, budaya populer

*Corresponding Author:

E-mail: pinckey.triputra09@ui.ac.id

rewindinar@gmail.com 


\section{INTRODUCTION}

\section{Fandom and Popular Culture.}

Japanese culture is one of the most attractive cultures because in addition to its diverse traditions, it also has its own uniqueness. Japanese cultural traditions are carried from generation to generation by their people/society but as technology develops, Japanese culture also develops. The tradition that was initially carried out as a ritual then developed into an entertainment value that could be enjoyed by other countries (Kristianto \& Marta, 2019)

Likewise, the presence of social media makes Japanese culture increasingly popular in various circles. Social media has become an active media in introducing various Japanese cultural products. Social media is currently the most used platform for people to communicate. Kompas survey in 2019 states that half of Indonesia's population has used social media and each of them has at least eleven social media accounts and that number will keep increasing (Pertiwi, 2019). So the higher media exposure plays a role in increasing the popularity of Japanese culture (Marta \& William, 2016). This also affected the presence of fans, namely Japanese popular culture fan groups.

These fans will always consume everything and look for information related to their likes (Indrayani \& Sunarto, 2019). This also applies to the group of fans or so-called Japanese cultural fandom. They will satisfy their passion for anything related to Japanese culture that they like, especially through social media.

Fandom exists in the contemporary society or (in another word) which is emphasized by Baudrillard with the term postmodern, where fandom is one of the cultures formed by mass media associated with digital, simulation codes and communication (Habib, 2018). Fandom is a form of hypereality where there is no difference between real life and the image presented on digital media.

The emergence of a fan group or socalled fandom, is very interesting to study. This is because fandom in social media is a virtual identity that is mostly done, especially among young people.
Fandom as a subculture reality that is based on participatory culture in which individual who is supposed to openly show the expression of his/her persona or identity as in real life actually uses a pseudonym identity on social media (Workman, 2015).

Research conducted by Ievansyah and Sadono (Ievansyah \& Sadono, 2018) addresses social media users' concern for the posts or texts they produce on social media. According to this study, social media users understand that their existence on social media will always be noticed by other (social media) users. They realize that there are two characteristics of other social media users who can like or dislike the posts (they) made. To see whether they like it or not, these social media users will monitor the responses given to their social media accounts such as seeing the number of viewers, comments and criticisms. The more viewers and positive responses mean (that) other social media users like (their posts). This can provide motivation to show more of what other social media users like. The more people who like it will also increase the number of friends on social media. Vice versa, negative comments and criticism can (also) have an impact on emotions from uncomfortable feeling.

Basically someone wants to look positive in the online world as they realize that the online world can have an impact on the real world. Therefore, when someone opposes something that can be offensive (on social media), it can cause controversy and conflict. However, social media users want to continue to present themselves according to their true desires, character and interests.

Every social media user wants to look more special than others. They also want to get a positive perception from others by posting something good through social media by considering the limitations of social rules in using social media, so that someone can realize what can or cannot be shared with the public.

Subsequent research shows how social media users can also freely give slanted comments, even inappropriate words. These negative comments are opinions given by someone that can be seen by the public. When there is a negative response, it can trigger other negative responses so that it can 
lead to opinions of other social media users or even cause social conflict in the real world (Marta, 2018).

Social media enables social interaction because social media is one of the technology products that people use to interact with others. Social media facilitates the interaction that is carried out both one-onone and with many people. This is due to the interactive nature of social media that uses internet technology. Therefore the pattern of communication of social interaction that occurs is at the level of individuals and groups (Sapoetri \& Pannindriya, 2019).

The use of social media becomes a person's daily routine activity with the aim of seeking pleasure and friendship (Ryan et al., 2014). Sharing personal dynamics, two-way interactions with others through networking platforms is a new trend in social interaction, entertainment, information transfer and facilitating instant interpersonal interaction (Chin et al., 2015). However, social media account owners cannot control the response or what other people display on their account (Krüger \& Johanssen, 2014).

Thus, social media users need to have good persona management on social media both between individuals and netizens (groups of people).

. The strategy of managing persona on social media to maintain the security and comfort of social media users is to use pseudonyms. Pseudonym is a conscious practice to leave identity artifacts through user ID or pseudonym. With pseudonyms, the text creator constructs his identity by making a name that is different from his/her real name. (Moll, 2014)

These practices, according to Chen, Chen, Lo and Yang (Chen et al., 2008), Barbour and Marshall (Marshall \& Barbour, 2015); Donath and Boyd, (Donath \& Boyd, 2004); and Moll, (Moll, 2014) are based on two motives, namely, first, to protect the security of privacy or personal identity so as to avoid threats to their original identities after releasing posts/works with sensitive issues and the second is, to avoid negative perceptions or stereotypes among the society (Hills, 2005), (Stanfill, 2013) This dual identity will be seen with a psychoanalytic approach.
Based on the conceptualization above, this study aimed to find out, motivate, and manage persona to avoid negative stereotypes that arise when someone practices pseudonyms on Facebook. In addition, this study also discussed the form of identity management that is carried out and the representation of persona in the fan accounts.

How social media users do their persona management and identity can be understood through this research by referring to the thoughts of David Marshall and Kim Barbour (Barbour \& Marshall, 2012), and Jacob Johanssen (Johanssen, 2019).

Based on Marshall's understanding (Marshall, 2010) setting is as one part of the front in the Goffman dramaturgy concept. Settings in the context of social media are defined as account profiles, images and messages displayed by individuals in social media, in this case the forms of messages are the status made, comments provided, and other content. Viewed from this perspective the construction of persona is a performance ritual of the self. This is a consequence of the vigilance of social media users when they realize that there are other social media users watching their social media accounts. Therefore, certain strategies are used by users to maintain and produce 'self' in the online world.

Marshall's view is more directed at the dynamics of production and construction of persona. When the process of selfconstruction is being built, there are various factors that influence the process of 'self' production and this can be explained further through Freud's psychoanalytic approach. According to Freud, in Johanssen, one's selfhood is basically identical to the concept of ego in Freud's psychic structure model (Johanssen, 2019), namely $I d, E g o$ and Superego. Self or ego is a product of the interaction between Id and Superego. Thus the character of self will be largely determined by how dominant the $I d$ or superego is.

Explanation of the research problem proposed above was done through an audience study approach that sees fans as active audiences and is then associated with Freud's psychoanalytic approach (Johanssen, 2019). Fans or fandom groups have the habit or culture to work as a form of self- 
expression. Someone who is a fan separates his/her identity as a fan and non-fan through two accounts on Facebook. Accounts with fans' identities use pseudonyms, while accounts for daily life (non-fans) in the real world (real life) use formal names. This seems like double identity is common among social media users, but actually this reality is a symptom that is driven by a person's psychological problems (Johanssen, 2019). Furthermore, to understand the presentation and construction of persona in online media, this study used the references of Jacob Johanssen (Johanssen, 2019) and David Marshall and Kim Barbour (Barbour \& Marshall, 2012).

Fandom is closely related to popular culture (pop-culture) in industrial society. One of the phenomenal fandoms is the existence of a group of fans of popular culture industry products from Japan, often referred to as J-Pop. There are various forms of J-Pop such as movies, music, anime, manga, comics or cosplay (costume play). In Indonesia, JPop was initially popular among young people in Jakarta and then spread to other big cities driven by celebrities and the media. Until now, the activities of fans or communities of culture lovers of this Cherryblossoms (Sakura) country are increasingly developing in Indonesia and becoming a public concern (Venus, 2017).

This fan group steadily selects media products and then makes them a culture or sub-culture (Fiske, 1992). Fiske explained that fandom has diverse productivity. This productivity fills the gap between cultural commodities produced by industry (such as narrative stories, music, or celebrities) and the daily lives of fans.

Fiske (Fiske, 1992) divides three kinds of fan productivity. First, Semiotics productivity is a popular cultural activity in general. This process only happens in fans to give personal satisfaction. Second is Enunciative productivity. The identity and meaning of the semiotic productivity of fans is shared with the public verbally (fan talk) and non-verbally. This division of meaning can be seen from body language such as the choice of makeup, accessories, how to dress or other symbols. Third is Textual productivity. It is artistic productivity that is close to products that become the fandom objects. Fans do not produce texts for profit, even though they require (certain) capital. The text produced by fans is not mass marketed so it will only circulate within the community. Through this productivity fans form their culture with their own production and distribution systems.

The J-Pop fandom case in this study focused specifically on the type of Semiotics Productivity. Of course, fans with this feature certainly cannot appear on social media without adequate knowledge in producing semiotic works on social media. One way to gain knowledge is to follow activities from one fandom to another. So actually the nature of fans is nomadic because it continues to move according to their needs by following more than one fan community or fandom and in this way fans get collective intelligence.

This concept is used by Pierre Levy in (Jenkins, 2006) to explain that the fan community not only has the knowledge sharing, but also the knowledge gained by a number of fans who are scattered like a puzzle that will continue to complement (each other). This behavior will continue to increase discourse and make the knowledge in the fan community continue to grow.

In her dissertation, Barbour (Barbour, 2014) discusses the realm of fans, namely about how a fan who has no formal background constructs his/her persona to be recognized by the public as a professional. This case, when seen with Freud's psychoanalysis used by Johanssen (Johanssen, 2019) is a picture of the compulsion motives of someone who wants to exist in the virtual world by using or doing persona management by which is using pseudonyms on social media.

Jenkins denied the notion that states fans as passive maniacs circulating in the community (Jenkins III, 1988) and Jenkins explained that in fandom there is actually a process of creative reproduction of media programs. They discuss, exchange meaning, do reinterpretation. The ability to change personal reactions into social interactions, spectator culture into participatory culture, is a major characteristic of fandom (Jenkins III, 1988).

Although Jenkins believes that fans are active, a fan needs psychological decisions to be active on social media. For 
example, to produce texts in social media, according to Johanssen (Johanssen, 2019) someone will consider whether the text they are going to write is contrary to the provisions or norms prevailing in society, or instead someone will just vent their desires without considering their social environment. This will apply to users of any type of social media.

One of the ideal social media that can describe what Jenkins said is Facebook. Facebook is a unique social media. It has the characteristics to display private matters, but its design and potential can be public.

In private matters, a person can present themselves according to their respective interests on Facebook such as food, clothing, music, admired/respected celebrities, including what accecories they worn. However these are also the expressions of individuals as social actors wherein the social media can mediate between users to interact with each other in it. Interactions that occur on social media facilitated by this technology are inseparable from social influence. This is because the user's behavior and feelings will be influenced by online representations of other users. Social media users as individuals will be associated with social objects because social media becomes a medium to interact with groups. (Rewindinar et al., 2019).

Kim Barbour in her dissertation discusses how the fan persona produced and controlled their identity in the online realm into three persona registers. First, the Professional register, which is the persona element displayed by individuals to the public through expertise and intelligence. Second is the Personal register, which is the persona element between the professional and intimate register. Personal registers are private but can be accessed by audiences in public and popular culture, such as hobbies, preferences, events and activities. Third is the Intimate register, which is a persona element that is more private than the personal register. The information that individuals share is at a level where it can only be seen by those closest to the individual.

The three types of persona registers allow individuals to adjust their persona according to the use. One can determine the persona displayed in a public or private context. The problem with this concept is how an individual can manage these elements. Persona is a strategy to determine which public and private rights through performance to play identity. This will relate to the characteristics of social media that have a variety of contexts for staying in touch with family, friends, colleagues, and even strangers. In online media, persona can be applied through web pages, social media. The way how someone presents his/her persona can be seen from any content that they send (post), like), share, or tweet (Barbour, 2014).

These three persona registers indicate that a person has a great motivation to keep using social media (Compulsion) because it is driven by the desire of Id (unconscious) to keep actualizing themselves on social media. Therefore, analysis of social media communication and psychoanalysis is interesting to do (Johanssen, 2019).

\section{Persona Management in Online Media}

David Marshall and Kim Barbour are scholars who adapted Erving Goffman's dramaturgy analogy to the study of persona in the context of online media. Marshall (Marshall, 2013) argues that persona is a form of presentation of how a person displays his/her identity to the public. Individuals will be more comfortable and free when building persona in online media rather than in offline (world) (Barbour \& Marshall, 2012). Online media are considered to be able to easily modify identity to the public that cannot be done in the real world. Although the identities are different in the real world, this can be done because the online world is more manageable by users compared to the offline (world). The (online media) user has power over the identity he/she wants to build. It is different from the offline world where individuals will be faced with norms or views of society. In addition, in online media individuals have a way to work around how to continue to present themselves without having to show (themsleves) directly (Lailiyah, 2015).

One's tendency to do pseudonyms is driven in part by the dynamics of the relationship between the Id and the superego. Pseudonym in this case can be interpreted as a result of the dominant aspect of the Id in this case. This means that someone wants to 
participate as a fandom because he/she is a fan of Japanese film products, but is not free and confident with him/herself, then he/she will do a pseudonym strategy, so that his/her real identity cannot be recognized by others. This strategy can also be seen as an attempt to construct pseudo identity, or so-called as management persona.

\section{Psychoanalysis, Management Persona and Pseudonym Construction}

Sigmund Freud's Psychoanalytic Theory provides a view of humans that is controlled by the unconsciousness in his mind (Siegfried, 2014). According to Freud the unconscious mind is a feeling, thought, insistence and memories that are outside a person. The unconscious mind is a process that occurs in the human mind that is not introspected.

Furthermore Freud said that most of the unconscious mind contains unpleasant things, such as feelings of pain, anxiety or conflict. The unconsciousness continues to influence one's behavior. The assumption in Freud's psychoanalysis is that humans are controlled by the unconscious thoughts that are below the surface of the conscious mind.

The three parts of the mind are id, ego and superego wherein the three parts are in the unconsciousness of the human mind. Id, all of which are the part of the unconscious mind, whereas the ego and superego, some parts are in the unconscious mind and some parts are in the conscious mind. This is because in a person's behavior although some parts are controlled by the person's unconscious mind, some others are in the person's conscious factor. This is influenced when someone is aware of the reasons and principles of reality and the rules that exist in society.

Id is a primitive part in the human mind. Id is a source of physical needs, will, desires and impulses. Id refers to the principle of pleasure or satisfaction that compels or motivates physically. Id is a selfish part and only thinks about the physical needs, without any consideration of values, good or bad and immoral. Id is the fulfillment of what is desired without ethical considerations.

Ego is a rational part of the mind. Ego represents a plausible reason. Eego has the principles of reality. Ego is related to interactions and relationships with others, understanding that other people are also driven by their own id and this urge can cause problems.

Superego is a moral part of society, which reflects internalization and cultural rules. Superego can be said as a conscience associated with the existence of feelings of guilt and related to the appropriate rules in social. Superego controls the sense of right or wrong and behavior that can be accepted by society.

Freud's Psychoanalysis Theory becomes the basis that gives a role when someone uses digital media in case of how someone as a subject behaves as a user (Johanssen, 2016a). If the superego is greater than the Id then the person will behave in inhibition, where a person will limit him/herself to avoid experiences that will add to anxiety. The actions of (online) media users will protect themselves so that nothing unexpected happens. Inhibition is shown by expressions that inhibit superego such as not sharing via Twitter tweet users. While social media is a medium where users can share with each other and this is the main goal of the social media Facebook, Twitter and so on.

But if the Id is greater than the superego then this will result in someone, as a digital media user, having compulsion behaviour. Compulsion behavior is shown through users who put emphasis on social media existence. They will communicate with each other and give expression to support the presence of the virtual community.

Inhibition and compulsion are products of the ego of social media users. Both are expressions that are demonstrated through the behavior in using social media as an act of persona management in social media. Thus unconsiousness where there are id, ego and superego in Freud's Psychoanalysis Theory is the basis of one's behavior as a user of social media.

Marshall's view is more directed at the dynamics of production and construction of persona. When the process of selfconstruction is being built, there are various factors that influence the process of 'self' production and this can be explained further through Freud's psychoanalytic approach. According to Freud, in Johanssen, one's selfhood is basically identical to the concept 
of ego in Freud's psychic structure model (Johanssen, 2019), namely $I d, E g o$ and Superego. Self or ego is a product of the interaction between Id and Superego. Thus the character of self will be largely determined by how dominant the $I d$ or superego is.

Explanation of the research problem proposed above was done through an audience study approach that sees fans as active audiences and is then associated with Freud's psychoanalytic approach (Johanssen, 2019). Fans or fandom groups have the habit or culture to work as a form of selfexpression. Someone who is a fan separates his/her identity as a fan and non-fan through two accounts on Facebook. Accounts with fans' identities use pseudonyms, while accounts for daily life (non-fans) in the real world (real life) use formal names. This seems like double identity is common among social media users, but actually this reality is a symptom that is driven by a person's psychological problems (Johanssen, 2019). Furthermore, to understand the presentation and construction of persona in online media, this study used the references of Jacob Johanssen (Johanssen, 2019) and David Marshall and Kim Barbour (Barbour \& Marshall, 2012).

\section{RESEACH METHODOLOGY}

Qualitative research has complexities related to human thoughts and behavior. In addition, the methodology in qualitative research is difficult to define because it does not have specificity in one method. Methodology is very dependent on the case chosen, namely how information and data are collected (Mohajan, 2018).

The methodology in this study was to interpret the epistemology of hypereality through pseudonym as a theory of postmodern culture. With this approach, the focus of research was on the characteristics of postmodern society.

In examining this pseudonym phenomenon, the research paradigm used is constructivism, with the understanding that the reality of pseudonyms that occur can only be understood through the interaction of social media users or the owner of an anonymous account with researchers. In this sense, agreement about the reality under study is generated through interaction between the researcher and the person being investigated.

Social media users or audiences provided a variety of information about what researchers need and what is known or experienced by those researched in this case are social media users. The first stage in obtaining data or information about the meaning of the reality of this pseudonym is, the researcher asked an unstructured question posed to two social media users, Facebook (Bryman, 2012).

Through this data collection method, information obtained by researchers is related to the habits, motives and meanings of using social media, specifically regarding the reasons for using pseudonyms or pseudonyms. These data were then processed and analyzed interpretively. In addition, the virtual ethnography methods were also used which departs from the virtual participatory observation method for the pseudonym account and the participant RL account. Interviews and observations were conducted in April to May 2016.

Research subjects focused on the fandom of Japanese popular culture that embraces participatory culture. While the object of research is an active audience informant through Facebook, namely fans who reproduce and reinterpret media products such as fan-video, fan-fiction, fan cover, fanart, cosplay, fan-dubbing, or other fan works.

\section{ANALYSIS AND DISCUSSION}

\section{Distribution of Japanese Popular Culture in Indonesia}

The entry of Japanese popular culture into Indonesia is closely related to the development of the media industry. The beginning of the influx of Japanese popular culture (Japan wave) in Indonesia began in the 1990s through Japanese drama films which were then followed by Japanese comics which were increasingly popular among teenagers and young people (Venus, 2017). This flow is also strengthened by the presence of Indonesian private television stations that have begun to import program 
content from abroad, including animated series from Japan (Badruddin, 2006).

This flow of Japanese popular culture influences how research informants were exposed to media products from Japan. Some informants admitted that they were initially interested when consuming Japanese media products through local conventional media such as watching Japanese animation, or reading translated Japanese comics.

Informants began to be exposed to conventional media that showed films from Japan since they were still in elementary school and then continued into adulthood.

\section{"It's been a long time since I}

liked Japanese, especially pop culture, since I I was in elementary school. Initially I like it normally, because of watching Doraemon and Inuyasha on TV. But, I started to delve deeper into the culture after $\mathrm{Yu}$-Gi-Oh series! was aired on Indonesia TVso it continues to the present [emoticon]" (Interview via the LINE messenger application with Neito, 30 April 2016).

"I like Japanese culture because of the comics and (my) friends, from the $3 \mathrm{rd}$ grade elementary school. My mother used to forbid me from buying comics like that, even though I've read Doraemon a number of times. When I moved home in Grade 3, in my new home someone left a comic (titled) candy candy, so I read it. Then my friend introduced me to local library close to my (house) area. Since then I frequently visit the library. [smile emoticon] Before, I only read novels, like Enid Blyton. Then when I was in grade 5-6, I started to take interest in the culture. Initially from the anime, then like the songs Popolocrois, $H x H$, Nube, Kindaichi and so, then from there became more aware of the cultural elements." (Interview via Facebook personal message with Fuicchi, April 26, 2016).

Fuicchi likes Japanese popular culture not only in one area, but (it) includes other fields such as print media, animation, and music. This is called Jenkins as fans interest. The longer the feeling of continuing to consume becomes a media routine that leads to building an identity.

From an industrial perspective, the use of multiplatform media is common in industries that have embraced the logic of convergence media. One of them is like the Cool Japan strategy which is run by the Japanese Ministry of Economy. This strategy was created by the creative industry division to help the country's economy by spreading creative content through various media (Ministry of Economy, 2012). In order for the creative industries to exist in this era of media convergence, they create great narratives in a variety of media texts, so that it cannot only be enjoyed by the audience through one medium (but through various media) (Jenkins, 2006)

One research informant, Heliotrope (in an interview on May 13, 2016) said that at the beginning he liked Japanese popular culture, his media behavior was limited to magazines, comics and television. The existence of the internet has a big influence by opening wider and richer information with the spread of information beyond the boundaries, as well as real time with what is happening in the country where the popular culture originated. After learning about the internet, Heliotrope said that he switched to accessing more Japanese content through the internet than in conventional media (in an interview on May 13, 2016). Digital media allows the practice of fans to be able to choose the content they want that conventional media cannot do (Krüger \& Johanssen, 2016)

The development of popular culture is never separated from the media industry and the development of media convergence. Jenkins (Jenkins, 2004) borrows Pierre Levy's concept of collective intelligence about the large-scale information gathering process that occurs in the internet community. This new community has a participant culture that is voluntary and temporarily affiliated with each other. This can be seen through the existence of collective knowledge and the growth of emotional ties in the community. Informants have the opportunity to give meaning to social experiences so that they increasingly 
form their identities as fans and have a sense of belonging in the community.

However, in interviews, all informants never called themselves "fans", but they positioned themselves as individuals who worked on fanworks. Informant Neito has a Tumblr with content containing the Kingdom Hearts game series. Tumblr followers often think that the account is a fan base that often shares information about Kingdom Hearts, even though the blog is a personal informant account.

\section{Practice of Pseudonim as Persona Management}

Every human being has multiidentity. Diverse identities relate to the social groups participants participate in. For that, individuals must be smart in their persona management towards their audience in accordance with the identity that they present. This study discussed (how) the participants construct their persona as fans through pseudonyms and explored how participants present their identities through two Facebook accounts as fans of Japanese popular culture and as ordinary people.

Each informant has their own background when deciding to practice pseudonyms. Referring to Fiske's three types of fan productivity (Fiske, 1992), informants tend to use pseudonyms on Facebook when entering textual productivity.

"For aliases, I can actually change (it) in each forum, I started to use permanent (alias) when there are already "works" that stick to my alias $x D^{\prime \prime} \quad$ (Interview via Facebook personal message with Fuicchi, April 26, 2016)

Fuicchi at first did not realize the potential to construct and build profiles through pseudonyms. He did this practice to mark the work he had produced, but his friends in his daily environment did not know that it was him who produced the work. Pseudonym makes a person identity or real information unknown (Mulawarman \& Nurfitri, 2017).

Aliases making that informants use as personas on Facebook is affected by the media products they consume.
"... Then at that time I wanted to use SC/ Utaite too, if it's hard to say to Japanese people / people who like Japanese (culture), it felt out of place, so I replaced (it)." (Interview via Facebook personal message with Fuicchi, 2 May 2016)

"Hmmmmm originally I wanted Nagito (the combination of the last name and nickname in Japanese pronunciation) but because there was a name called Nagito (too) so I used the nickname in Japanese pronunciation to become Neito" (Interview via LINE messenger application with Neito, April 30, 2016)

The name (used) which is influenced by Japanese popular culture is also a sign that the person has an identity as a fan of Japanese popular culture. Because each individual is part of a diverse group, the individual develops his multi-identity by playing the identity game that he will display. This relates to the analogy of Goffman's dramaturgy (Goffman, 1956):

"So in IRL, I usually work in NGO [NGO name is obscured]. Besides being a program manager, I am also often asked to go to events to be a representative and take material. The last time I went to Bogor, it was part of the drafting of a Child Friendly School policy from the Ministry of Education and Culture's Directorate of Basic Education. XD When is the date? Middle of March? But after the comif open the registration, I permit not to participate in other events first, so I can focus on work. So at that time, I focused more on the work behind the scenes, the website and the preparation of the home schooling program (it was a bit hectic)." (Interview via Facebook personal message with Fuicchi, 26 April 2016)

One important concept in selfpresentation is the presence of an audience. Personal front view elements are divided into appearance and behavior. These elements relate to the roles performed and expected expectations regarding the relationship between appearance, setting (Goffman, 1956). 
Marshall (Marshall, 2010) does not separate the existence of backstage and frontstage when discussing persona through online media as in Goffman's. This is because online media has a different context from everyday life (offline).

He only explained that the front elements can be seen as account profiles, messages, and images that individuals display on social media. All kinds of texts contained in Facebook accounts are forms of persona construction.

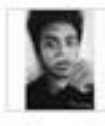

\section{Gada Ferlatus Tahier}

13 hrs - Jakarta, Indonesia - \&.

\section{Sebagian jiwa pindah kesiniii ::}

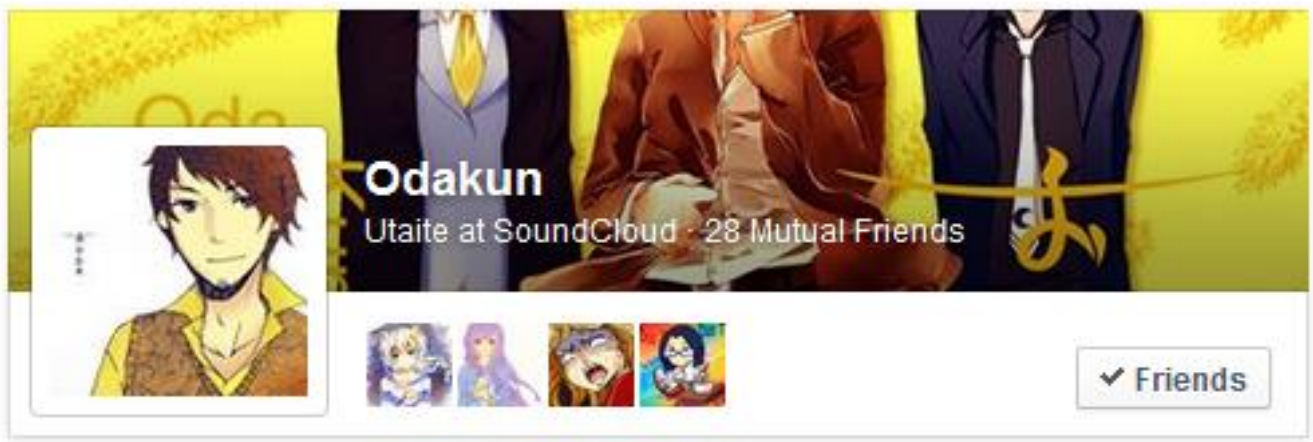

Figure1. The example of persona construction; Oda's status that shared the link to his Facebook pseudonym account (Source: Facebook)

The picture above shows the RL Account of the participant named Oda sharing the link to his Facebook pseudonym account. One form of the front element in Marshall's online persona concept (Marshall, 2010) can be seen from how he uses different profile photos for the two accounts he manages. The $\mathrm{RL}$ account uses an original photo that shows his face, while the pseudonym account uses an illustrated image. The names for the two accounts are also different. RL accounts use real names, while pseudonym accounts use alias names.

The illustration illustrates that Oda has an identity as a fan of Japanese popular culture. The formal identity in Oda's pseudonym account is not filled with official work and institutions that he shelter, but rather filled with his position in fandom, namely as utaite, cover singer-song Japanese singer.

In addition, from several mutual friends that Oda and researchers have, it appears that they also use illustrated images as their profile photos. This shows that they are both fans of Japanese popular culture, and the Oda pseudonym account is indeed devoted to friendship in a fandom environment.

If you glance without looking at the context and deeper background, ordinary people will doubt whether the two accounts are owned by one person. However, both are the original identity of Oda, it's just that he selected certain symbols to represent the identity he has.

Having multiple identities becomes a problem if the identities appear simultaneously when they are in one time and one place. One of the cases occurred in Facebook's virtual space. Facebook social media is a personal place where we can put our identity, share activities and other content. However, it is very interactive with the audience, that is, friends who are in social media friendship by commenting on content shared on social media accounts. This shows that in addition to private, Facebook is a 
public space that facilitates communication that can be perceived differently by each user (Fensi, 2019). This is because everyone has a language that can be interpreted differently by each person who comes from a (certain) background.

\section{Stereotype Threats and Role Disagreement with Audience Expectations: Inhibition and Compulsion}

Researchers found the avoidance of stereotypical threats became one of the main motivations of fans to practice pseudonyms. The existence of negative views from nonfans to fandom participants makes them uncomfortable to show their activities on their daily network of friends.

"Hmm yeah, maybe because my cosplay is secret and only my closest friends know. In addition, I also see that society in general still thinks that Japanese (especially cosplay) is something negative, uncommon, and strange. I also feel that my family does not need to know the details about my cosplay activities "(Interview via LINE messenger application with Neito, May 1, 2016)

"... My mom is very supportive even she likes to show off to her office friend (Japanese company too) if I (participated in) cosplay. My father doesn't like it, but if I ask him to take me to the event, he will do it anyway, with non-stop nagging of course.. "The crazy person": ') / sorry for a little whinning" (Interview via Facebook personal message with Schia, May 3, 2016)

"My parents are the type of people who are work/ class first', so if their children are caught in a hobby, they can be removed instantly from the family card lol " (Interview via Facebook personal message with Daichi, May 4, 2016)

An informant named Daichi (in an interview on May 4, 2016) said that his parents are an obstacle to practicing fandom culture. He was threatened with isolation and expelled from his family and social groups.
All of his activities to make fan work are done by him in secret. This is because he lives in conservative environments that are more concerned with work and study. If there are stereotype and also restrictions by parents in the family then this become a consideration for someone not to appear on social media, this is interpreted as inhibition. Thus the superego factor is more dominant than the id factor.

On the other hand there are also fears of getting stereotyped threats from the online world. On the internet, we can find people from a variety of backgrounds, so there is a great opportunity for thoughts to be different from the cultural backgrounds thoughts of other countries. These different thoughts can be reflected in the response to what is displayed by the Facebook account owner (Johanssen, 2016b).

Often these responses have an adverse effect or are a burden on the Facebook users' mind. This feeling according to Freud's view is a feeling caused by what someone did or something someone saw on social media (Johanssen, 2018).

"... this account was intended for the foreign community. I don't want to present myself as a veiled girl, $i$ am afraid to be judged weirdly" (Interview via Facebook personal message with Fuicchi, 2 May 2016)

This veiled informant feels free to express opinions and is comfortable to express herself without fear of negative stereotypes from ordinary people. Convenience to continue to express like this, means the Id factor is more dominant than the superego so that it becomes a motive for continuing to participate in the world of social media, and this is what Johanssen said (Johanssen, 2019) as a compulsion.

The behavior of a person who identifies (themselves) as a fan of Japanese popular culture sometimes also behaves in a manner that is not in line with the expectations of the behavior expected by the social environment in the real world.

"So most of my friends in the $R L$ don't know that I am actively 
selling, producing, and working with senior artists. They mostly see $R$ as a religious girl who is not interested in business or develop herself at all, even though yha 8))) "(Interview via LINE messenger application with Heliotrope, May 4, 2016)

Sometimes, they do not display their activities in the practice of fandom culture. Like Heliotrope, she is someone who is active in religious activities. Actually, Heliotrope is an active participant in fandom, often even selling works at comic convention events, or opening drawing services.

"... (it) doen't match (my RL character) and this seems to be the main cause I'm still afraid to tell people that heliotrope $=R w w w$. My account hasn't been clean [emoticon]" (Interview via LINE messenger application with Heliotrope, May 14, 2016)

Heliotrope acknowledges that there is a mismatch when comparing her persona in RL accounts and pseudonym.

\section{Persona Management Strategies in Facebook Social Media}

In accordance with the construction of persona in the Marshall concept (Marshall, 2010), this management is carried out by informants by setting the settings in the front element. Although the informants said that they were the same in each account, there were differences in the content the informants sent and shared, as well as the different styles of speaking from each account. This difference follows with how the audience and context of each account belongs to the informant.

"Very different haha. The content shared are different. Here, I started from the beginning-when I used to chat non-stop, with all caps lock, (being) all furious, all emojis. Over there, more restricted (image managing)? Maybe? ... " (Interview via Facebook personal message with Fuicchi, 2 May 2016)

"The difference is the way I laugh, Poetry is hahahaha, while Ken is usually wwwww. Then after that, the hair is different, one is black, one is white. The gender is different, one girl while one is in doubt. ....... Ken is weaboo, weaboo version is Poetry " (Interview with Ken, May 4, 2016)

"Because I am active in Islamic activities and come from a family / environment that holds a lot of Islamic values, I am more likely to share the matter on $R$ 's Facebook. While the other, is a special account to share what I like in general (and not many people know RL) "(Interview via the online Messenger application with Heliotrope, 4 May 2016)

With pseudonyms, informants are free to express opinions, express themselves without worrying about negative views and feel comfortable with friends with other pseudonyms. These informants tend to maintain the persona in the RL account, but in the pseudonym account everything becomes loose.

Although in Barbour and Marshall's argument (Barbour \& Marshall, 2012), chosing and selecting process is more when individuals present their identities in digital media than in the offline context, researchers find that the informants' speaking style in a pseudonym account is more expressive than the informants' RL account. Informants are also more active in sharing and sending information through their pseudonym accounts.

\section{CONCLUSION}

The internet has become a space for users to provide opportunities in developing their own persona (Moll, 2014). One practice is through the practice of pseudonyms via Facebook social media. This research began with the researchers' curiosity to see the phenomenon in the Japanese popular culture 
community, wherein each of its members make additional accounts.

Research questions about the extent of productivity when they decide to practice pseudonyms get mixed answers. Fans practice pseudonyms to protect their members as fans and also want to protect their privacy in real life and in the online world. Thus fans in the realm of the internet have unique practices in managing their persona.

The thoughts of Erving Goffman, David Marshall, and Kim Barbour who were at the core of this study turned out to have flaws in discussing the phenomenon of persona management through pseudonyms by Japanese popular culture fans. Three personal, public, and intimate register concepts (or self in thought (Marshall, 2010)) in Barbour's thinking (Barbour, 2014) are blurred because the pseudonym practice that fans do on Facebook makes their members both public and private.

This concept is better applied in the case of pseudonyms by using the fanpage feature on Facebook, because using fanpage to construct personas in the public sphere does not require friend requests to fandom participants who do so. So, it will be easy to see the contrast of their fanpage and personal account.

The existence of technological advances make fans use the features in Facebook to manage their persona. The practice of persona management on Facebook becomes more complex as there are block, unfriend, list, untag, unfollow, privacy settings, and rules so that no one can search for their Facebook account name in the search field.

\section{REFERENCES}

Badruddin, Y. (2006). Penggunaan Media dalam Konstruksi Identitas di Era Globalisasi: Studi Kasus pada Penggemar Animasi dan Komik Jepang di Jakarta. Jurnal Penelitian Ilmu Komunikasi, 5(3), 75-110.

Barbour, K. (2014). Finding the edge : online persona creation by fringe artists. CPIS 2014: Persona, celebrity, publics: Proceedings of the Contemporary Publics 2014 International Symposium,
15-16. Diambil dari

http://dro.deakin.edu.au/eserv/DU:3006 1131/barbour-findingedge-2014.pdf

Barbour, K., \& Marshall, D. (2012). The academic online: Constructing persona through the World Wide Web. First Monday.

https://doi.org/10.5210/fm.v0i0.3969

Bryman, A. (2012). Social Research Methods. OUP Oxford.

Chen, H.-G., Chen, C. C., Lo, L., \& Yang, S. C. (2008). Online privacy control via anonymity and pseudonym: Crosscultural implications. Behaviour \& Information Technology, 27(3), 229242.

https://doi.org/10.1080/0144929060115 6817

Chin, C.-Y., Lu, H.-P., \& Wu, C.-M. (2015). Facebook users' motivation for clicking the "like" button. Social Behavior and Personality: An International Journal 43.4, 579-592. https://doi.org/10.2224/sbp.2015.43.4.5 79

Donath, J., \& Boyd, D. (2004). Public Displays of Connection. BT Technology Journal, 22(4), 71-82. https://doi.org/10.1023/B:BTTJ.000004 7585.06264.cc

Fensi, F. (2019). Paradoxic Language "Cebong-Kampret" in Facebook as a Mirror of the Political Language of Indonesia. Bricolage: Jurnal Magister Ilmu Komunikasi, 5(2), 103-120.

Fiske, J. (1992). The Cultural Economy of Fandom. In L. A. Lewis (Ed.), The Adoring audience: fan culture and popular media (hal. 30-49). London: Routledge.

Goffman, E. (1956). The presentation of self in everyday life. Edinburgh: University of Edinburgh.

Habib, M. M. (2018). Culture and Consumerism in Jean Baudrillard: A Postmodern Perspective. Asian Social Science, $14(9), \quad 43$. https://doi.org/10.5539/ass.v14n9p43

Hills, M. (2005). GET A LIFE?: FAN CULTURES AND CONTEMPORARY TELEVISION Lauri Mullens, editor, Spectator 25:1 (Spring 2005): 35-47. 35, l(Spring), 35-47.

Ievansyah, \& Sadono, T. (2018). Personal 
Branding dalam Komunikasi Selebritis (Studi Kasus Personal Branding Alumni Abang None Jakarta di Media Sosial Instagram). Bricolage, 4(2), 149-162.

Indrayani, H., \& Sunarto. (2019). Fandom: Marketing Communication Strategy 3 . 0 to Strengthen The Fantation of Nationalism Through Sports. Bricolage, 5(1), 15-30.

Jenkins, H. (2004). The Cultural Logic of Media Convergence. International Journal of Cultural Studies, 7(1), 3343.

https://doi.org/10.1177/1367877904040 603

Jenkins, H. (2006). Convergence Culture: Where Old and New Media Collide. New York: New York University Press.

Jenkins III, H. (1988). Star Trek rerun, Reread, Rewritten: Fan Writing as Textual Poaching. Critical Studies in Media Communication, 5(2), 85-107.

Johanssen, J. (2016a). Media research and psychoanalysis: A suggestion. International Communication Gazette, 78(7), 688-693. https://doi.org/10.1177/1748048516655 730

Johanssen, J. (2016b). Not belonging to one's self: Affect on Facebook's site governance page. International Journal of Cultural Studies, 21(2), 207-222. https://doi.org/10.1177/1367877916666 116

Johanssen, J. (2018). Towards a Psychoanalytic Concept of AffectiveDigital Labour. Media and Communication, 6, 22-29. https://doi.org/10.17645/mac.v6i3.1424

Johanssen, J. (2019). Psychoanalysis and Digital Culture: Audiences, Social Media, and Big Data. New York: Routledge.

Kristianto, B. R. D., \& Marta, R. F. (2019). Simplifikasi Ritual Harai dan Dimensi Kultural Hofstede dalam Iklan Forte Versi Sumo. Brocolage: Jurnal Magister Ilmu Komunikasi, 5(1), 91102.

Krüger, S., \& Johanssen, J. (2014). Alienation and Digital Labour-A Depth-Hermeneutic Inquiry into Online Commodification and the Unconscious. tripleC: Communication, Capitalism \&
Critique. Open Access Journal for a Global Sustainable Information Society, 12(2), 632-647. https://doi.org/10.31269/triplec.v12i2.54 8

Krüger, S., \& Johanssen, J. (2016). Thinking (with) the unconscious in media and communication studies: Introduction to the special issue. CM: Communication and Media, 11(38), 5-40. https://doi.org/10.5937/comman1113131

Lailiyah, N. (2015). Presentasi Diri Netizen dalam Konstruksi Identitas di Media Sosial dan Kehidupan Nyata. Jurnal Ilmu Sosial, 14(2), 20-35.

Marshall, P. D. (2010). The promotion and presentation of the self: Celebrity as marker of presentational media. Celebrity Studies, 1(1), 35-48. https://doi.org/10.1080/1939239090351 9057

Marshall, P. D. (2013). Persona studies: Mapping the proliferation of the public self. Journalism, 15(2), 153-170. https://doi.org/10.1177/1464884913488 720

Marshall, P. D., \& Barbour, K. (2015). MAKING INTELLECTUAL ROOM FOR PERSONA STUDIES: A NEW CONSCIOUSNESS AND A SHIFTED PERSPECTIVE.

Marta, R. F. (2018). Polemik Kebhinnekaan Indonesia Pada Informasi Instagram @Infia_Fact Terkait Patung Kwan Sing Tee Koen Tuban. Bricolage: Jurnal Magister Ilmu Komunikasi, 3(02), 6371.

https://doi.org/10.30813/bricolage.v3i02 .922

Marta, R. F., \& William, D. M. (2016). Studi Terpaan Media Pemasaran Melalui Posting Instagram Terhadap Ekuitas Merek Pelanggan Sumoboo! Jurnal Komunikasi Untar, 8(1), 68-82.

Ministry of Economy, T. and I. (2012). Cool Japan Strategy. METI: Ministry of Economy, Trade and Industry, (January). Diambil dari http://www.meti.go.jp/english/policy/m ono_info_service/creative_industries/pd f/120116_01a.pdf

Mohajan, H. (2018). Munich Personal RePEc Archive Qualitative Research 
Methodology in Social Sciences and Related Subjects Qualitative Research Methodology in Social Sciences and Related Subjects. Journal of Economic Development, Environment and People, $7(85654), 1$.

Moll, E. (2014). What's in a Nym? Gender, Race, Pseudonymity, and the Imagining of the Online Persona. M/C Journal; Vol 17, No 3 (2014): persona. Diambil dari http://www.journal.mediaculture.org.au/index.php/mcjournal/artic le/view/816

Mulawarman, M., \& Nurfitri, A. D. (2017). Perilaku Pengguna Media Sosial beserta Implikasinya Ditinjau dari Perspektif Psikologi Sosial Terapan. Buletin Psikologi, 25(1), 36-44. https://doi.org/10.22146/buletinpsikolog i. 22759

Pertiwi, W. K. (2019). Separuh Penduduk Indonesia Sudah "Melek" Media Sosial. Diambil 18 Maret 2020, dari https://tekno.kompas.com/read/2019/02/ 04/19140037/separuh-pendudukindonesia-sudah-melek-media-sosial

Rewindinar, Triputra, P., \& Dua, M. (2019). Mamah Muda Morphogenesis in Indonesia. South Asian Journal of Social Studies and Economics, 4(3), 111.

https://doi.org/10.9734/sajsse/2019/v4i3 30128

Ryan, T., Chester, A., Reece, J., \& Xenos, S. (2014). The uses and abuses of facebook: A review of facebook addiction. Journal of Behavioral Addictions, 3(3), 133-148. https://doi.org/10.1556/JBA.3.2014.016

Sapoetri, A., \& Pannindriya, T. (2019). Geliat Interaksi Sosial Dokter Masa Kini Melalui Media Sosial Instagram. Bricolage: Jurnal Magister Ilmu Komunikasi, 5(2), 121-140. Diambil dari https://journal.ubm.ac.id/index.php/bric olage/article/view/1884

Siegfried, W. (2014). the Formation and Structure of the. : : Undergraduate Philosophy Journal, 62(2), 1-3. https://doi.org/10.1002/pssa.221009010 7

Stanfill, M. (2013). “They're Losers, but I Know Better": Intra-Fandom
Stereotyping and the Normalization of the Fan Subject. Critical Studies in Media Communication, 1-18. https://doi.org/10.1080/15295036.2012. 755053

Venus, A. (2017). Budaya Populer Jepang di Indonesia : Catatan Studi Fenomenologis Tentang Konsep Diri Anggota Cosplay Party Bandung. Jurnal ASPIKOM, 1(1), 71. https://doi.org/10.24329/aspikom.v1i1.9

Workman, K. (2015). That's My Fan Name: The Use Of Pseudonyms In Fandom Communities. Diambil 23 Februari 2016, dari http://mediacommons.org/imr/2015/05/0 5/thats-my-fan-name-use-pseudonymsfandom-communities 